\title{
THE PROBLEM OF THE TREATMENT OF VENEREAL DISEASE IN THE MERCANTILE MARINE*
}

\author{
By A. O. ROSS, M.D., D.P.H.
}

SAILORMEN are in some ways a race apart. They live together, a small cosmos, for long periods of time, with nothing around them but grey seas. No news of the outer world reaches them for many days at a time, and news when it does come is only of the main events. This causes the ordinary sailorman to be very circumscribed in his thoughts and conversation.

After days of seafaring a port is entered, probably foreign and probably unpleasantly hot. The day is spent in painting the ship and in the evening the sailorman goes ashore to forget the dull monotony of the many days' voyaging. What does he find to engage his attention? There is the ever-present saloon with its bright lights, fiery liquids, and painted ladies. There is the picture house, where inability to understand the captions does not necessarily render the picture unintelligible. Even there, however, the seaman is not entirely free from the attentions of the ubiquitous fille de joie. There is no place in the world of which this picture is more true than the large South American ports, and so Para, Pernambuco, Buenos Aires, and Valparaiso import into Liverpool other articles than are shown on the ship's bill of lading.

Again, the sailorman is bone lazy, thanks to the confined quarters in which he has to spend his life at sea, and to the dull monotony of his daily outlook. Even in such a fine city as Liverpool he spends his days, if the day be warm enough, propping up the Board of Trade offices or the Institute in which he has spent the night. The evenings, so long as the money lasts, are spent in the crowded bars not three minutes from his bed-oftentimes a wise precaution. But to these bars or, after closing

* Paper delivered before the Medical Society for the Study of Venereal Diseases, April 5th, 1929. 


\section{VENEREAL DISEASE IN MERCANTILE MARINE}

time, to the supper saloon or chip shop, there also drift the female vampires of dockland. So whether he stops ashore at Lagos or Liverpool the same temptation assails our sailorman, and the summation of stimuli at length breaks down the strongest resolve.

The foregoing does not apply to all sailormen. The men who serve in the large liners of the first-rate shipping companies cannot retain their employment if they do not retain their self-resepct. In addition, routine medical inspection before being signed on for a new voyage acts as a deterrent to loose living. Other refinements of life are theirs-daily exercise, clean quarters and possibly recreation grounds ashore. Many of these men are Royal Naval Reservists, and the discipline inculcated at our naval barracks bears perennial fruit. But the remainder, who man tramp steamers and who never do two voyages in one ship or with one company, are very much as described. These men when infected with venereal disease may or may not report at the treatment centre, but few continue treatment until cured. They are too lazy to follow out instructions given verbally, too lazy to read the short notes on treatment printed on every patient's identity card, and too fond of mine host's nut-brown ale. They are employed without previous medical examination, and so chronic nephritis goes to sea with aortitis, and urethritis is looked upon as a sign of youth !

Liverpool has tried to help the lot of this type of sailorman. There are three large institutes with sleeping accommodation for over 300 men. These institutes are for seamen only, and have large billiard rooms and reading rooms. In addition there is a Scandinavian Sailors' Home, a home for Spanish Seamen, and an African Hostel under the ægis of the Elder Dempster Co. In Birkenhead, where most of the ships from India and the East dock, there is a home for natives of British India. At the large institutes, where a bed may be obtained from $7 d$. per night, or a week's board and lodging for $18 s .6 d$., scarcely an evening passes but some form of amusement is provided for the men, although it may be only a lecture on venereal diseases. In addition, the institutes are visited by many of the prominent personages who spend a day or two in Liverpool. Admiral Gordon Campbell, V.C., and Lord Ampthill have recently visited, and the 


\section{BRITISH JOURNAL OF VENEREAL DISEASES}

Lord Mayor from time to time shows his interest. There can be no doubt that these little attentions add to the morale of the men. We await, however, the grand gesture of the shipowners who have it in their power to allocate better and more roomy quarters to the men at sea. The Merchant Shipping Act demands only I20 cubic feet of living space per man, and our ships compare most unfavourably with the ships of many other nations, where one cabin is shared by two men. Our men in many cases eat and sleep in a mess deck, where the requirements of the Merchant Shipping Act are barely complied with. Until some determined effort is made to improve the conditions in which these men live, and until the discipline of the ship makes for the increased self-respect of each member of the ship's company, we shall continue to have more venereal disease.

According to Professor Koolemans Beijnen, nearly one-third of all the cases of primary syphilis treated in Holland are treated at the Rotterdam Seamen's Clinic. He deduces from this the fact that syphilis in Holland is largely an imported disease. Similarly, chancroid in Liverpool appears to be very largely a disease of seafarers. Seamen chiefly patronise the Seamen's Dispensary, but a few go for treatment to the clinic at the Royal Southern Hospital. These two clinics are the only two clinics which see chancroid to any extent. The other three clinics do not see one case of chancroid in Ioo cases of penile ulcer.

In Birkenhead, where many of the ships on the Far East trade dock, quite an appreciable percentage of chancroid cases are seen-one to every five of syphilis. At the Seamen's Dispensary one case for every three of syphilis is diagnosed as chancroid. That the small percentage of chancroid seen at the three other clinics in Liverpool is not due to faulty diagnosis is proved by the fact that the Medical Officer in charge of the Royal Southern Hospital clinic is also in charge of one of the other clinics, and he rarely sees a case of chancroid except at the Royal Southern clinic. It is of interest to note the proportion of chancroid to syphilis in the health report of the Army in 1926 and the report on the health of the Navy for 1925. For the whole Army chancroid exceeded syphilis in the proportion of six cases to four. For the Home Army syphilis exceeded chancroid by five cases to 
two. In the Navy chancroid exceeded syphilis in the proportion of eleven to eight. Should the Government ever take a strong line in dealing with venereal disease, there is a weapon ready to hand. At present the firstclass shipping companies appoint a medical officer to examine each member of the ship's company before he is engaged for the voyage. Thus these shipping companies are enabled to reject any man who is suffering from venereal disease. Any man found suffering from venereal disease is referred to a clinic for treatment and is not re-engaged until the medical officer of the clinic certifies that he is fit for sea. By an extension of this method, as described in a letter I sent to Mr. David Lees in October, I927, one could control the importation of venereal disease to a very appreciable extent. To quote from this letter:-

" . . The matter of retaining seamen on shore until the acute stage of gonorrhœa is past and until one complete course of anti-syphilitic treatment has been given has interested me for some considerable time. It should be easy of accomplishment in the case of men who continue in the service of one company whose men are regularly examined before proceeding upon another seatrip. Such a company is typified by Alfred Holt \& Co., of Liverpool, whose trips average three and a half months sea time, and with this company I have very harmonious dealings. All men who report to the ship's surgeon during the voyage are treated by him and very often by the Singapore clinic, who issue a $V 44$. When the ship docks here the men report to me and quite often carry a note from the surgeon as well as the bald statements given on $V$ 44. The ship's surgeon reports these patients to the medical department of the company, and before they are allowed to go to sea again they must have a note from me as per copy enclosed. The weakness in the system is that these men are not treated by the ship's surgeon on this occasion, as more expert treatment is required than the ship's surgeon can provide, and thus these men may continue to go to sea until the disease relapses. The keener fellows, of course, report to me on their return home, and obey my instructions as to the length of time they require to remain ashore. Many, however, do not report here again and so are lost sight of. To overcome this leakage it would be necessary for all 
uncured V.D. cases to be borne on the sick book of the ship's surgeon, whether receiving treatment or not, and that on returning to Liverpool they are again reported to the company's medical department, who will again require a note from the M.O. Treatment Centre before allowing the man to proceed to sea. This routine should be continued until a note signifying complete cure is issued by the M.O. Treatment Centre. It is a ticklish business, because the medical departments of shipping companies are not so keen on work as we are, and if they found that our methods entailed more work for them, they would simply refuse to take a man to sea unless given a clean bill of health. We, on the other hand, cannot expect to be popular with the seamen if for two years or more we continue to refuse this clean bill of health. ... All this pertains only to those desirable companies in which the men desire to be kept employed.

" With the 'tramp' company matters are entirely different, and in a port such as Liverpool it would be necessary to establish a central medical bureau where men about to sign on in any ship whatsoever are required to pass a medical officer who knows the wiles of the sailorman. (Retired naval surgeons would be admirable if they were of the keen type such as are given recruiting billets in our large ports by the Admiralty when they leave on pension.) Any man found suffering from venereal disease in a contagious form could have his 'book' temporarily taken from him until such time as he was able to show a certificate from a competent M.O., that the infectious nature of the disease was allayed for so many months. The 'book' would then be returned to the seaman and he would be allowed to sign on for a voyage of less duration than stated on the certificate. On his return from the voyage his 'book' would be automatically abstracted from him if a proper filing system were instituted at the central bureau. This 'book' could also be marked in some inconspicuous way, and thus, if any man eluded the filing system, he would be "hung up " on attempting to sign on for the next voyage. ...'

Up to the present no such scheme has been put into operation, but with the sanction of Parliament and the co-operation of the Board of Trade such a system would be of the utmost value. 
The respective percentages of infections diagnosed at the Seamen's Dispensary are : Gonorrhœa, 6I per cent. ; syphilis, 29 per cent. ; chancroid, Io per cent. In 3,500 consecutive cases I,070 were infected in Liverpool, and one-third of these were infected by amateurs (I 5 per cent. of my patients are non-seafaring townspeople). London was responsible for I39 (2I being amateur infections) and the other home ports for 383 ( 78 being amateur infections). Europe supplied 593, of which IIo were from Hamburg, 56 from Marseilles, 3I from Rotterdam, and 27 from Genoa.

South America is undoubtedly a plague spot. From the Brazils there were I9o infections : II9 from River Plate ports and I34 from Valparaiso.

West Africa supplied I24, chiefly negroes.

Dutch East Indies, China, Japan, India, U.S.A., and the West Indies were responsible for 6o each.

Canada with 38 (27 from Montreal), Australia with 33 and New Zealand with 2 make us hopeful of the Dominions overseas.

Of European maritime nations, Sweden with I and Denmark with 8 are shining examples.

Of the types of infection the "Pernambuco sore" is characteristic. It is a large superficial ulcer with a sloughy base, oval or rhomboid in form, and extending from the edge of the prepuce to the meatus on the ventral aspect of the penis. The frænum, by the time Liverpool has been reached, has gone entirely, leaving no trace. Suppurating buboes as a sequel are not common, and the Wassermann usually is negative and remains so; in fact, a chancroid with a predilection for the frænum.

Valparaiso and the Mediterranean ports are renowned for gonococcal infections, and, as Valparaiso is a five weeks' voyage from Liverpool, epididymitis is a not infrequent occurrence.

From Dutch East Indies and Jamaica I have from time to time seen a urethritis characterised by a long incubation period of four to six weeks, and a trifling amount of muco-purulent discharge containing epithelial cells, leucocytes and extra-cellular Gram-positive cocci and bacilli. The blood Wassermann is repeatedly negative in the cases I have seen.

Many of our cases come from the Far East, and I should like to say here that the clinic at Singapore appears 


\section{BRITISH JOURNAL OF VENEREAL DISEASES}

not only to be necessary, but of very great value as administered at present. The treatment of gonorrhœa is started in earnest there, and the medical officer seems to be able to get the ships' surgeons interested in the treatment of venereal disease. Irrigations for the cases of gonorrhœa, together with injections of sulfarsenol and massive doses of vaccine, are arranged for, and my part in the case is, in very many cases, simply to declare the patient cured.

As to nationalities and attendances, out of 3,000 cases 540 were foreign. Norwegians accounted for 104 of these, and I have found them (and the same is true of the Danes and Swedes) very attentive to treatment. They do their utmost to come back for successive courses of treatment for syphilis. West African negroes (I02) used to be very bad attenders, but lately a working partnership between the manager of the African Hostel and myself has borne fruit. Negroes are chiefly in the employ of the Elder Dempster Shipping Company, and the hostel in which the men live when ashore is the property of this firm.

Natives of British India are notoriously bad attenders. They make their first appearance at the clinic either alone and destitute of English, or surrounded by a host of messmates who quickly fill the waiting room with their persons and their gibberish. Many times I have seen a busy hour before me on looking into the waiting room, but when the next case is called all rise and advance. After some parley one of the gang, called the sirang, acts as interpreter for the unfortunate afflicted, and thereafter matters proceed smoothly until one proceeds to do a vein puncture or to incise a suppurating bubo. Then one finds that the use of a needle is a sore point with the Hindu. A second attendance is rare. Dutch and German captains usually bring their own men and act as interpreters. If the vessel is not homeward bound men with acute infections are sent home direct.

With British seamen I try to persuade acute cases to " sign off" their ship. A note recommending this course is carried by the man to his captain, stating that the bearer is unfit for sea service and should be paid off forthwith. Few men are taken to sea in face of this certificate. More chronic cases I allow to go to sea, but make them agree to return for treatment at the expiry of 


\section{VENEREAL DISEASE IN MERCANTILE MARINE}

their agreement. I do not believe in giving a case of syphilis an injection of novarsenobenzene and permitting him to vanish into the unknown accompanied only by a $V 44$ transfer book. Unless the movements of the ship can be foretold for the next ten weeks, and the probability of procuring injections not less than once weekly is good, I do not believe in using novarsenobenzene. Instead I produce a stock of case sheets which demonstrate the possibilities of success with regular injection treatment, and another set of case sheets which show with startling clearness the results of irregular injection treatment. A little trouble taken to show how necessary treatment is results in regular attendances.

As seamen earn their livelihood by going to sea, a speeding-up of treatment is necessary. For this reason the usual course of $5.7 \mathrm{gm}$. N.A.B. and $3.6 \mathrm{gm}$. bismuth metal is compressed into thirty-nine days by giving biweekly injections of bismuth throughout and alternating doses of 0.45 and $0.6 \mathrm{gm}$. N.A.B. bi-weekly for eight doses, and $0.75 \mathrm{gm}$. on two occasions thereafter at one week's interval. After the thirty-ninth day the man is given a certificate of fitness for three months. In three months' time a blood Wassermann is taken and a similar course given. If the blood is negative a twenty-five days' course $(4 \cdot 2$ gm. N.A.B. ; 2.4 gm. bismuth) is insisted upon and a similar course given six months later. To date I have not seen a sero-negative case becoming positive within three months of the end of the first course provided strict attention is paid to the bi-weekly injections, but in several cases where broken treatment has occurred, that is, where one week instead of four days has elapsed between two of the first six injections of N.A.B., a positive result has been returned. I will give the figures: 65 cases were treated regularly and the blood remained negative. Four cases were treated at irregular intervals and 3 became positive. Success and failure in sero-positive cases in the same way depends upon the regularity of treatment. I think you will all agree that it is a much easier task to treat a case of syphilis with a positive blood which has had no novarsenobenzene treatment than a case which has had novarsenobenzene treatment without altering the positivity of the blood.

Illustrating this fact and also the necessity for regular v.D. 
treatment are the figures of all the late latent cases that I have had under treatment. In 23 cases where previous novarsenobenzene treatment had failed to affect the positive nature of the blood, regular treatment had the effect of causing a negative Wassermann to be returned three months after the termination of the course in 8 cases. Fifteen cases remained positive.

On the other hand, where 44 late latent cases had received no N.A.B. treatment, 35 cases became negative and 9 only remained positive. Ten cases which had received no previous arsenical treatment and which were treated at irregular intervals did not respond to treatment, and all remained positive. In all cases $5.7 \mathrm{gm}$. of N.A.B. were given and $3.6 \mathrm{gm}$. of bismuth, but the success of this treatment was much influenced by previous arsenical treatment and by irregular arsenical injections. The point I wish to make clear is that it is bad treatment to give irregular treatment and bad administration to allow a patient to wander from clinic to clinic while he is undergoing arsenical treatment unless one is certain that treatment will be absolutely regular. In such cases the probability of the blood becoming negative after one course is small, and if the first course fails to accomplish this desirable end the probability of further treatment, regular and sustained though it be, achieving serological success is greatly reduced. In such cases I give bismuth only, intra-muscularly, or if the voyage entails a fortnight or more of sea-time I give a tube of colloidal bismuth inunction cream, "suspensol" by name, in selected cases. This cream is put up in collapsible tubes, and daily inunctions of a 3 -inch ribbon of this ointment, equivalent to I gr. of bismuth metal, is recommended.

Before leaving the subject of syphilis perhaps I ought to say that I have not yet seen a penile ulcer treated on board ship with saline. Black wash and calomel cream still obscure the treponema.

The treatment of gonorrhœa at sea is again a matter of accommodation. In the privacy of a cabin an irrigator may be slung and treatment carried on, but such a course is obviously impossible in the publicity of a mess deck. The use of a small hand syringe in the privacy of a watercloset at first sight appears to be a way out, but if one remembers the lack of asepsis, the indiscriminate use of $2 \mathrm{I} 8$ 
antiseptics, and the difficulty of smuggling a pot of warm water into a water-closet without arousing suspicion, the feasibility of proper treatment by such means is extremely problematical. In my opinion, the average patient who resorts to the small hand syringe is laying up a store of chronic folliculitis in his anterior urethra. So the only proper place for the treatment of gonorrhœa is ashore.

Unfortunately, one cannot be so definite about the length of treatment required in a case of gonorrhœa, and yet one must not discourage the patient too much. The minimum requirements before I allow a man to go to sea for three months are: There is no discharge; the urine is clear, with a few shreds at most ; the prostatic secretion must contain at most " a few pus cells," and irrigation with I/I0,000 silver nitrate solution does not provoke discharge or turbidity of the urine. The man is given plainly to understand that he is still under treatment- that rules of diet and conduct still hold-and that he must come back prepared to spend a month under treatment. This plan works well, and it suits the majority of seamen better than continuous treatment.

In the treatment of syphilis the seaman who suffers most is the deep-sea sailor, as it is absolutely essential for him to give up his employment if he is to be cured. Fortunately for the medical officer, his honeyed words and persuasive manner are greatly helped by the diagnosis, for syphilis is rated high among the undesirable episodes in a sailor's life. On the other hand, the bugbear of the clinical medical officer's life is the man engaged in the coasting trade who has contracted gonorrhœa. This man will not give up his job and his sporadic attendances are of no value. So his treatment drags on from month to month, and cure remains for ever on the unattainable horizon.

As for the contempt in which gonorrhœa is held, the following episode speaks for itself: A seaman was admitted to Haslar Hospital with stricture of the urethra, and the medical officer of the ward received emphatic negatives to his queries regarding former attacks of syphilis or gonorrhœa. Finally he ejaculated in desperation, "Do you mean to say you have never had clap?" To which the old salt replied, "Clap, did ye say? Man, I'm a fair martyr to it !" 